\title{
Reserva Extrativista Marinha Mestre Lucindo (PA): processo de criação e perspectivas para o turismo
}

\section{Mestre Lucindo Extractive Marine Reserve (PA, Brazil): Creation Process and Tourism Perspectives}

\author{
Raul Ivan Raiol de Campos; Mara Dayane Silva Nascimento; \\ Symone da Costa Mendonça
}

\section{RESUMO}

O objetivo geral do presente estudo foi analisar a participação e o envolvimento da comunidade local no processo de criação Reserva Extrativista Marinha Mestre Lucindo localizada no município de Marapanim no estado do Pará. Teve como objetivo específico identificar quais comunidades da REM que já trabalham com o turismo e saber as expectativas dos usuários da REM para o futuro do turismo na referida Unidade de Conservação. Para o desenvolvimento do estudo foram realizados levantamentos $\mathrm{e}$ análises em bibliografias que forneceram subsídios teóricos e conceituais para a pesquisa. A pesquisa de campo foi realizada com entrevistas e aplicação de questionários, bem como a observação do modo de vida de duas comunidades. Os resultados mostram que a maioria da população desconhece que seu território se tornou uma Unidade de Conservação, mas associam a criação da UC com a melhoria na qualidade de vida. O turismo acontece de forma desornada, embora a REM tenha grande potencial turístico. Porém, há falta de planejamento e organização. Propõe-se o planejamento do turismo de base comunitária para valorizar o conhecimento tradicional e atividades sustentáveis das comunidades locais.

PALAVRAS-CHAVE: Participação; Reserva Extrativista; Unidades de Conservação; Turismo; Comunidade. 


\section{ABSTRACT}

The main objective of the current study was to analyze the participation and involvement of the local community in the process of creation of the Mestre Lucindo Extractive Marine Reserve located in the municipality of Marapanim in the state of Pará (Brazil). The specific objectives were to identify which communities of the Extractive Reserve already work with tourism and to know the expectations of the Reserve users for the future of tourism in this protected area. For the development of this study, surveys and analysis were conducted to provide theoretical and conceptual basis for the research. Field research was conducted involving interviews and application of questionnaires, and also observation of daily lives of two communities. The results indicate that the majority of the people living in the Reserve is unaware that their territory became a protected area, but they relate the protected area creation as an improvement of life quality. Tourism takes place disorganized, however the Reserve has a great touristic potential. But, it lacks proper planning and organization. It is proposed community-based tourism planning in order to value tradicional knwoledge and sustainable activities of local communities.

KEYWORDS: Participation; Extractive Reserve; Protected Area; Tourism; Community.

\section{Introdução}

O presente trabalho teve como objeto de estudo a Reserva Extrativista Marinha (REM) Mestre Lucindo, uma Unidade de Conservação (UC) recémcriada no Litoral Norte do Estado do Pará, que possui diversas diversidades naturais e culturais que são atrativas para o turismo. Este tipo de UC, segundo Sistema Nacional de Unidades de Conservação (SNUC) pertence ao grupo das unidades de uso sustentável ou de uso direto, que permite a presença de populações humanas vivendo na área da reserva (BRASIL, 2000).

O tema Reserva Extrativista (RESEX) possibilita a ampliação do debate sobre a categoria REM, cada vez mais presente no cenário do amazônico. A escolha do tema deve-se a importância que a REM Mestre Lucindo possui por suas características sociais, culturais e turísticas. A REM foi criada em outubro de 2014, porém, são poucos os estudos a seu respeito. A principal fonte de pesquisa é o Estudo Socioambiental de criação da REM, desenvolvido pelo Instituto Chico Mendes de Biodiversidade (ICMBio).

A REM Mestre Lucindo apresenta um grande potencial turístico, por suas belas paisagens, áreas naturais, praias oceânicas e o próprio modo de vida das comunidades pesqueiras e extrativistas. A atividade turística já se encontra presente em algumas comunidades e no seu entorno, mas de forma não planejada.

Este trabalho possibilita pensar o turismo na REM de forma crítica e numa perspectiva sustentável, visando a conservação dos recursos naturais e a preservação da cultural local, pois grande é a possibilidade do desenvolvimento do turismo que venha se adequar a dinâmica local. Como apontando por 
Coriolano (2009), o turismo comunitário que tem crescido no mundo inteiro, não só no litoral do Brasil, mas também em áreas protegidas.

Este estudo teve como objetivo geral analisar a participação e 0 envolvimento da comunidade local no processo da recém-criada Reserva Extrativista Marinha Mestre Lucindo localizada no município de Marapanim no estado do Pará. Teve como objetivos específicos identificar quais comunidades que já trabalham com o turismo e se há planejamento nas atividades lá desenvolvidas, bem como, saber as expectativas dos usuários da REM para o futuro do turismo na referida UC.

Para alcançar os objetivos proposto no trabalho foram feitas pesquisas bibliográfica e documental em instituições públicas e privadas a fim de se fazer um levantamento sobre a área pesquisada e para construir o referencial teórico. Segundo Gonçalves (2007) a pesquisa bibliográfica caracteriza-se pela identificação e análise dos dados escritos em livros, artigos de revistas e publicações. Dessa forma, na pesquisa bibliográfica foram utilizados para consulta: livros, artigos científicos, teses e dissertações. Além de diversas publicações de órgãos públicos e privados que forneceram dados sobre a área de estudo.

As abordagens quantitativa e qualitativa foram adotadas na pesquisa de campo. Para Minayo e Sanches (1993), a pesquisa qualitativa tem como foco a análise de crenças, valores, hábitos, representações, atitudes e opiniões. Segundo Oliveira (2008) na pesquisa quantitativa, há uma ênfase nos dados empíricos que são coletados sistematicamente, de modo rigoroso e estruturado e analisado estatisticamente.

A pesquisa quantitativa foi usada para obter dados sobre as variáveis sociais, econômicas e sobre a relação das comunidades com a REM. Para este tipo de pesquisa foi questionário com perguntas fechas e abertas. A técnica utilizada na pesquisa qualitativa foi a entrevista semiestruturada. Este tipo de entrevista, segundo Rosa e Arnoldi (2006, p.31) consiste de "[...] avaliação de crenças, sentimentos, valores, atitudes, razões e motivos acompanhados de fatos e comportamentos".

A pesquisa de campo foi primeiramente realizada nos meses de julho de 2015 e posteriormente nos dia 18 e 19 de 2016. A primeira etapa da pesquisa de campo foi realizada nas comunidades de Vista Alegre e Tamaruteua. Foi feita a aplicação de 40 (quarenta) questionários estruturados com perguntas abertas e fechadas com os moradores locais de Vista Alegre, Tamaruteua, Marapanim, Crispim e Recreio. Foram realizadas entrevistas com representantes das comunidades entre eles, o presidente da Associação de Usuários da REM Mestre Lucindo (AUREMLUC).

A segunda etapa da pesquisa foi direcionada para o setor público. Desse modo, foi possível entrevistar o representante da Secretaria Municipal do Meio Ambiente (SEMMA) do município de Marapanim.

$\mathrm{Na}$ pesquisa de campo foi usada imagística etnográfica (LABURTHETOLRA; WARNIER, 1997), principalmente a fotografia cuja função não é somente visual. Para Collier (1973, p.7), a arte fotográfica "[...] é um dos 
primeiros passos na expressão mais apurada da evidência que transforma circunstâncias comuns em dados para elaboração de pesquisa". Portanto, a fotografia é tão importante quanto qualquer outro documento para a pesquisa científica.

\section{Unidades de Conservação na Amazônia e Estado do Pará}

O processo de seleção de áreas naturais tem na sua origem uma relação direta com a história da humanidade. O homem desde os primórdios buscou formas de interação com ambiente na busca pela sua sobrevivência. De acordo com Guerra e Coelho (2009) o homem frente ao desafio da vida, passou a selecionar determinadas áreas naturais pela sua capacidade de recursos disponíveis, necessários para a manutenção e sobrevivência do grupo. Esta seleção está presente desde o início do desenvolvimento das sociedades.

Segundo Vallejo (2002) durante a Idade Média houve na Europa algumas intervenções realizadas pela aristocracia, classe social dominante, que possuía grande parte das propriedades. A seleção realizada por este grupo consistia em destinar áreas naturais para o uso exclusivo de alguns reis e proteção de determinadas espécies. Mas, a principal mudança na relação do homem com a natureza se deu a partir da Revolução Industrial que teve início na Inglaterra durante o século XVIII e difundiu-se pela Europa durante o século XIX.

O mesmo autor ressalta que, nesse processo, o homem decidiu substituir - campo pela cidade transformando totalmente o seu modo de vida $e$ consequentemente suas relações de trabalho. Essa emigração ocasionou no crescimento e urbanização das cidades, mas, trouxe também diversos problemas ambientais resultantes da atividade industrial, que explorava de forma intensa os recursos naturais. Este fenômeno ocorreu, tanto nos países europeus caracterizados como potências do capitalismo como nas suas referidas colônias.

As áreas protegidas são, segundo Medeiros (2003), espaços territorialmente demarcados onde sua principal função é a preservação ou proteção de recursos naturais e culturais a eles associados. A primeira área protegida a ser legalmente criada no mundo foi o Parque Nacional de Yellowstone em 1872. Seu processo de criação do parque teve como base ideológica a corrente preservacionista que foi implementada nos Estados Unidos como forma de resguardar ecossistemas e paisagens naturais da ação predatória do homem (DIEGUES, 1994).

Para compreender melhor o processo de criação da categoria Parque Nacional Diegues (1994) explica que, no início do século XIX, havia nos Estados Unidos duas correntes teóricas em discursão: 0 conservacionismo e 0 preservacionismo. O conservacionismo foi criado pelo engenheiro florestal Gifford Pinchot, sua teoria defendia o uso racional dos recursos naturais permitindo a presença do homem em áreas protegidas, onde, este poderia utilizar-se dos recursos de maneira sustentável e eficiente.

O preservacionismo, segundo Diegues (1994), era representado pelo naturalista John Muir, defendia uma vertente oposta, no qual a natureza devia ser apenas reverenciada e apreciada pela estética da vida selvagem (wilderness), 
seu uso destinado a atividades de lazer e caráter educativo. Sua teoria encontrou subsídios nos textos de Darwin e John Muir mostra-se um preservacionista puro. Para ele era preciso proteger a natureza da ação do homem e mantê-la intocada, longe do desenvolvimento moderno, industrial e urbano.

Nesse sentido, nota-se que o Parque Nacional de Yellowstone representou uma vitória dos preservacionistas, pois no interior do parque não era permitido a presença de populações humanas vivendo no mesmo espaço. $O$ modelo de preservação que foi estabelecido em Yellowstone sofreu diversas críticas ao longo dos anos, principalmente pela restrição de uso do seu território destinado apenas ao lazer e a pesquisa, sendo assim o parque evidenciava a beleza de seu ecossistema, mas excluía a importância do homem para a manutenção da biodiversidade do lugar, o que ocasionou na desapropriação da população local que habitava esse espaço há milhares de anos (VALLEJO, 2002).

Compreende-se que a proteção da natureza através da criação de áreas protegidas pelo Estado, fundamentado na corrente preservacionista nem sempre foi a melhor solução para os problemas ambientais no mundo, principalmente se analisados sobre a ótica dos países menos desenvolvidos (DIEGUES, 1994). Portanto, a abertura do diálogo sobre a presença de populações em Áreas Protegidas foi de grande importância, pois diminuiu as contradições e possibilitou novas estratégias de conservação da natureza. Esses fatores vão incidir diretamente no objeto de estudo desse trabalho, a REM Mestre Lucindo, uma área legalmente protegida que abriga no seu interior populações tradicionais que vivem e dependem desse espaço.

No Brasil, o Código Florestal de 1934 foi de suma importância porque definiu as tipologias de áreas de áreas que seriam legalmente protegidas (MEDEIROS, 2006). Assim, em 14 de junho de 1937 o Parque Nacional de Itatiaia foi estabelecido através do Decreto $\mathrm{n}^{\circ} 1.713$, com base no código florestal de 1934. O parque foi a primeira unidade de conservação do país, localizado entre os estados do Rio de Janeiro e Minas Gerais. Sua criação se deu a partir da inclusão da área que pertencia à antiga Estação Biológica do Itatiaia, administrada pelo Jardim Botânico do Rio de Janeiro, onde inicialmente, esta área possuía 11.943 hectares e foi ampliada pelo Decreto $n^{\circ} 87.586$ de 20 de setembro de 1982 para 30.000 hectares (BRASIL, 2004).

Diegues (1994) ressalta que, o Parque Nacional de Itatiaia foi criado com o propósito de incentivar a pesquisa científica e oferecer lazer às populações urbanas. Porém, consequentemente o seu processo de criação foi influenciado pela ideologia norte-americana de preservação e implantação de parques, tornando Itatiaia uma área de uso restrito e não permitindo que populações tradicionais habitassem seu território.

A primeira área protegida a ser criada na Amazônia legal foi o Parque Nacional do Araguaia, em 1959, localizado no estado do Tocantins possuindo $5.577 \mathrm{~km}^{2}$. Em seguida, entre as décadas de 1960 e 1990 novas unidades foram estabelecidas, principalmente a partir de 1985 quando os estados da Amazônia Legal se engajaram também no processo. Mas, cerca de $90 \%$ dessas unidades, estavam sobre jurisdição federal (VERÍSSIMO et al., 2011). 
Para Lima (2002) O aumento expressivo na criação de UC, deve-se a pressão política internacional que se mobilizou contra o aumento de queimadas, desmatamento e outros efeitos da política de desenvolvimento na Amazônia presente desde a década de 1980. Como exemplo, a autora cita que, 21 das 33 Florestas Nacionais, foram criadas em apenas três anos (1988 a 1990), no entanto, a maioria dessas unidades ficou apenas no papel, pois na prática a questão ambiental não recebia nem apoio político, nem adesão popular, já que essas áreas foram estabelecidas de forma autoritária, sem consulta à sociedade local.

O grande avanço no cenário amazônico das UC ocorreu entre os anos de 1990 e 2000, quando o Governo Federal criou novas categorias de manejo mais condizentes com a realidade da região (LIMA, 2002). Houve, portanto, o surgimento da Reserva Extrativista (RESEX) e da Reserva de Desenvolvimento Sustentável (RDS), categorias de manejo que vieram atender às dificuldades de implantação de reservas ecológicas intocadas, representando uma nova estratégia de UC no Brasil.

Nesse aspecto Figueiredo (2010, p. 18) mostra que:

Desde 2000, quando as RESEX passaram a integrar o SNUC, tem sido crescente a institucionalização de UC dessa categoria na Amazônia brasileira. Em virtude da demarcação dessas áreas, ocorreram mudanças positivas e significativas no que se refere aos aspectos de organização e apropriação do território e as políticas públicas de gestão desses espaços.

Desse modo, as categorias RESEX e RDS apresentam-se condizentes com a realidade da Amazônia, pois, permitem a manutenção de populações tradicionais na unidade e visam promover o uso sustentável dos recursos naturais, combatendo o desmatamento ilegal na região, possibilitando uma nova configuração de áreas protegidas na Amazônia que a partir de 2003 vivencia um boom na criação de novas UC, tanto federais, como estaduais (BRASIL, 2000; LIMA, 2002).

Até dezembro de 2010 a área total protegida na Amazônia brasileira correspondia a 1.174.258 Km², distribuídos em 307 UC. Desse total, 196 eram de Uso Sustentável e 111 de Proteção Integral, sendo que, a administração de 132 unidades era realizada pelo governo federal e 175 pelos governos estaduais. Neste cenário, o estado do Amapá liderava a posição de maior proporção de UC tendo $61 \%$ do seu território preservado, em seguida aparece 0 Acre com 34, 2\%, o Pará com 32,3\% e o estado do Mato Grosso com 4,6\%, este apresentava a menor proporção de UC. Para a gestão dessas UC é preciso ter recursos humanos e financeiros adequados, estrutura básica como sede, vigilância, equipamento de emergência e comunicação e, sobretudo, um Plano de Manejo aprovado que, de acordo com o SNUC, este é o principal instrumento de gestão em qualquer UC (VERÍSSIMO et al., 2011; BRASIL, 2000).

É importante ressaltar que, no ano de 1997 o governo brasileiro assinou um compromisso internacional de proteger integralmente $10 \%$ do bioma 
amazônico e que nos anos 2000, foi assinado o projeto para a Expansão e Consolidação de Áreas Protegidas na Amazônia (Projeto ARPA) entrando em vigor a partir de agosto de 2002 pelo Decreto 4326/2002. Inicialmente, este projeto objetivou a implantação de 18 milhões de hectares de novas UC de proteção integral e propôs tirar do papel 15 outras unidades, criadas anteriormente. No entanto, o ARPA teve o financiamento do Global Enviromental Facility (GEF), que consiste em um fundo administrado pelo Banco Mundial (LIMA, 2002; BRASIL, 2008).

Desse modo, o ARPA é um programa do Governo Federal de conservação e uso sustentável das florestas tropicais brasileira, que protege de forma representativa a biodiversidade na Amazônia. Atualmente, seu objetivo principal é proteger e implementar 50 milhões de hectares de UC, assim como, contribuir para a consolidação do SNUC através da sua expansão e sustentabilidade financeira. O ARPA é coordenado pelo Ministério do Meio Ambiente e implementado através de uma parceria entre os órgãos gestores de UC, o Fundo Brasileiro para a Biodiversidade (Fumbio) e a Cooperação Técnica Alemã - GTZ. Sua execução se dá através de recursos alocados pelos governos e recursos provenientes de doações não governamentais como da ONG internacional Fundo Mundial para a Natureza (WWF) Brasil, do GEF por meio do Banco Mundial, do Entwicklugsbank - KFW e de empresas como o Boticário e a Natura que juntas contribuem financeiramente (BRASIL, 2008).

As últimas intervenções do Governo Federal na Amazônia direcionadas à criação de novas UC foram realizadas em outubro de 2014, com a implantação de três novas Reservas Extrativistas Marinhas (REM) e a ampliação de duas RESEX já estabelecidas, uma no estado do Amazonas, e outra no estado do Pará. No entanto, cabe ressaltar que, nesta ação foram criadas ao todo sete novas unidades distribuídas entre os estados de Minas gerais, Paraná e Pará. Desse modo, o Brasil conta agora, com 903 mil hectares de área protegida em todo o território nacional (BRASIL, 2014).

As ações governamentais refletem a preocupação do governo com a proteção dos recursos naturais na Amazônia, haja vista que, há décadas a região vem sendo observada pelos olhares do mundo. Essa observação na Amazônia deve-se, em parte, ao processo de ocupação que o espaço amazônico foi submetido, em que a ausência de políticas públicas voltadas para a conservação dos recursos naturais exigiu um alto preço da natureza, principalmente pelo efeito negativo do desmatamento que até hoje impera na região (GONÇALVES, 2008).

Desse modo, é preciso acordar para as mudanças que desafiam o futuro da Amazônia e reverter o quadro de devastação estabelecido ao longo dos anos, para que haja para as gerações futuras um cenário natural preservado e utilizado de forma sustentável, onde os novos atores aprendam a conviver com a diversidade que caracteriza a região.

Contudo, pode-se perceber que há um interesse, tanto do governo, como de populações locais em preservar a Amazônia e a forma encontrada para esse objetivo foi a criação de UC. Esta atitude foi um fator decisivo para o futuro da região, principalmente por garantir a manutenção dos ecossistemas amazônicos 
e de suas populações tradicionais (CUNHA, 2010). Assim, o grande desafio para gestores e ambientalistas na Amazônia não é apenas garantir a implantação de novas UC, mas principalmente inserir a população local no processo.

\section{Reservas Extrativistas}

O surgimento das RESEX possui na base do seu contexto histórico uma ligação direta com o processo de ocupação da Amazônia a partir do início dos ciclos da borracha na região. O primeiro ciclo da borracha ocorreu entre o final do século XIX e o início do século XX, precisamente entre os anos de 1879 a 1912. O principal fator contribuinte para este fenômeno foi o desenvolvimento da indústria automobilística após a descoberta da vulcanização do látex por Charles Goodyear. No entanto, o látex que produzia a borracha era extraído da seringueira (Hevea brasiliensis), árvore presente apenas na floresta amazônica, o que consequentemente atraiu a Inglaterra e muitos países europeus interessados pelo látex e fez dele a principal matéria prima exportada da Amazônia (RIBEIRO, 1992; SARGES, 2010).

As RESEX, segundo Allegretti (2002), surgiram a partir dos conflitos que envolveram seringueiros, novos imigrantes, grandes proprietários e fazendeiros da região, gerando um ambiente de instabilidade e tensão, ocasionando na morte de muitos inocentes que decidiram lutar pelo direito à terra. $E$ nesse contexto, de lutas e contradições, que é forjada a categoria de manejo RESEX. Criada no final da década de 1980, diante da necessidade de regularização fundiária na Amazônia, em decorrência dos inúmeros conflitos por terra que envolviam populações tradicionais historicamente presentes na região.

O conceito de RESEX é, sobretudo, resultado da luta dos seringueiros do Acre pela proteção da floresta frente ao desmatamento, mas também uma proposta de utilização sustentável dos recursos naturais, através de uma legislação ambiental que conciliasse o uso dos recursos e a regularização fundiária dos espaços de populações tradicionais (CHAMY, 2002; CUNHA, 2003).

Cunha (2003) explica que as RESEX surgem em contraposição aos projetos de colonização que se estabeleceram na Amazônia durante as décadas de 1970 e 1980 e ao modelo de desenvolvimento implantado que foi totalmente alheia às configurações socioambientais da região.

A estratégia definida pelos seringueiros em 1970 foram os Empates, que consistia em um movimento formado por seringueiros e líderes sindicais com o objetivo de impedir a derrubada da floresta pelos novos fazendeiros da região, mas, também de lutar contra a desapropriação de seus territórios (ALLEGRETTI, 2002). Este movimento teve como principal líder Chico Mendes, que insatisfeito com as condições de vida dos trabalhadores e habitantes da floresta, torna-se defensor desses povos e do meio ambiente, organizando os trabalhadores, para lutar de forma pacífica a favor de seus direitos e contra a violência exercida na região. No entanto, a forte resistência dos seringueiros através dos empates, geraram frequentes conflitos, resultando na morte de muitos povos da floresta (ALLEGRETTI, 2002; UNIÃO INTERNACIONAL DE CONSERVAÇAO DA NATUREZA, 1995). 
De acordo com Allegretti (2002) em Março de 1990, houve também, a criação da RESEX Chico Mendes, com quase um milhão de hectares de floresta e abrangendo seis dos 22 municípios do Acre, estabelecida nas áreas onde antes havia os conflitos. A categoria de manejo RESEX é definida pelo SNUC como:

[...] uma área utilizada por populações extrativistas tradicionais, cuja subsistência baseia-se no extrativismo e, complementarmente, na agricultura de subsistência e na criação de animais de pequeno porte, e tem como objetivos básicos proteger os meios de vida e a cultura dessas populações, e assegurar o uso sustentável dos recursos naturais da unidade (BRASIL, 2000).

A RESEX veio modificar totalmente o modelo de conservação existente no Brasil e na Amazônia, que até 1984 havia apenas UC de proteção integral. A implantação do novo modelo de reservas pressionou a revisão da legislação que regulamenta as UC no Brasil. Essa regulamentação veio através do SNUC a partir de 2000 (LIMA, 2002). Segundo Medeiros (2006), o SNUC incorporou categorias a partir de experiências originais como as RESEX que surgiram da base da sociedade.

O SNUC divide as UC em: Unidades de Proteção Integral e Unidades de Uso Sustentável. As UC de Proteção Integral têm como objetivo "preservar a natureza sendo admitido apenas o uso indireto dos seus recursos naturais" (BRASIL, 2000). As UC de Uso Sustentável têm como objetivo "compatibilizar a conservação dos recursos com o uso sustentável de parcela de seus recursos naturais" (BRASIL, 2000).

A RESEX é uma UC de Uso Sustentável, sua posse e domínio são públicos com uso concedido às populações extrativistas tradicionais (SNUC, 2000). Somente a partir da RESEX houve, de fato, o reconhecimento de comunidades tradicionais e sua importância para a manutenção do meio ambiente. Após a criação da RESEX foram intensificados os seminários e debates envolvendo a participação da sociedade civil no processo de criação e gestão das UC (ALLEGRETTI, 2002).

Assim, pode-se afirmar que a RESEX representa não só a vitória do movimento social dos seringueiros do Acre, mas, foi, sem dúvidas, um grande avanço na trajetória de UC no Brasil. Principalmente, por ser uma categoria de UC que de fato é compatível com a região amazônica, dando importância, tanto natureza, como a sua população, buscando uma relação sustentável entre eles.

No caso da RESEX a gestão da unidade deve feita pelo Conselho Deliberativo que é formado pelo órgão responsável por sua administração (ICMBio), por representantes de órgãos públicos, de organizações da sociedade civil e das populações tradicionais residentes na área. No entanto, cabe ressaltar que, este mesmo Conselho Deliberativo é responsável pela aprovação do Plano de Manejo da unidade (BRASIL, 2015; BRASIL, 2000).

Atualmente existe na Amazônia legal 37 RESEX, das quais 23 estão no Estado do Pará e pertencentes também a classificação de reserva extrativista 
marinha, ou seja, unidades estabelecidas em zonas costeiras ou marítimas (BRASIL, 2015). A primeira RESEX criada no estado do Pará foi a Reserva Extrativista Tapajós-Arapiuns no ano de 1998.

A categoria Reserva Extrativista Marinha (REM) tem aumentado significativamente nos últimos anos, principalmente no litoral nordeste paraense que tem como características a riqueza em recursos hídricos, uma imensa área de manguezais e grande atividade pesqueira. A primeira REM criada no estado do Pará foi a RESEX de Soure, no ano de 2005. No entanto, esse modelo expandiu-se pelo litoral nordeste paraense que atualmente possui um conjunto de 11 (onze) REM.

Contudo, compreende-se que a categoria de manejo RESEX difere das outras UC, por dar prioridade à população local e ser uma área destinada ao uso sustentável dos recursos naturais, garantindo o direto à terra e melhorando a qualidade de vida das populações extrativistas e costeiras (CHAMY, 2002). A classificação de REM proporcionou não só, a inserção de novas populações, como contribuiu, para a conservação da biodiversidade dos ecossistemas de manguezais, restingas, dunas, várzeas, campos alagados, rios, estuários e ilhas tão presentes no cenário da Amazônia brasileira.

\section{Turismo em RESEX}

A presença do turismo em UC mostra-se cada vez mais comum no cenário turístico brasileiro. Este fator deve-se ao grande potencial que as áreas naturais possuem, bem como, os diversos atrativos culturais pertencentes às podem as comunidades tradicionais que habitam este espaço. Segundo Mattos (2008) nas UC de uso sustentável, como é o caso das REM, muitas comunidades tem o desejo de trabalhar com o turismo pelas possibilidades que a atividade oferece. Dessa forma, a presença do turismo em REM pode ser uma alternativa de complementar a renda das familias que vivem exclusivamente da atividade pesqueira e extrativista.

Para Araújo (2012) as modalidades de turismo que podem ser desenvolvidas em uma UC como a RESEX, por exemplo, é o ecoturismo ou turismo de base comunitária, sendo que, de acordo com a autora, o ecoturismo busca utilizar de forma sustentável o patrimônio natural, fortalecendo também a cultura e a identidade local. O turismo de base comunitária é uma modalidade viável para as comunidades principalmente para a RESEX, pois, caracteriza-se como um segmento alternativo, que busca a interação do turista com a natureza, envolvendo também a comunidade local às práticas sustentáveis de desenvolvimento econômico.

Assim, a mudança socioeconômica vinculada ao turismo possibilita o desenvolvimento da atividade e a inclusão social, através, do envolvimento de populações locais que definem o que é importante no seu ambiente. Pois, o turismo comunitário é aquele em que as comunidades de forma associativa organizam arranjos produtivos locais e ficam no controle efetivo das terras e das atividades econômicas associadas à exploração do turismo. No turismo comunitário, o turista é direcionado a interagir com o lugar e com as famílias 
residentes, seja de pescadores, ribeirinhos, pantaneiros ou de índios (CORIOLANO, 2009).

Portanto, o turismo comunitário é uma forma de turismo diferenciado, que não visa apenas à acumulação de capital, mas, proporciona que todos os moradores interessados possam participar de forma igualitária. Nessa perspectiva, o interesse do turista, também, é direcionado para a combinação dos vários elementos naturais, culturais e sociais que compõe a paisagem da RESEX.

Na RESEX Chico Mendes, Araújo (2012) mostra o exemplo de desenvolvimento da atividade turística. Localizada no estado do Acre, foi criada em 1990, possui uma área de 970. 570 hectares aproximadamente. De acordo com a autora, a RESEX é uma área utilizada por populações tradicionais, cuja subsistência baseia-se no extrativismo e na agricultura, no entanto, a presença do turismo mudou este cenário.

A RESEX Chico Mendes possui um cenário paisagístico exuberante em meio a floresta amazônica, onde é possível o turista ter uma relação íntima com a natureza, ver árvores centenárias gigantescas, ouvir o canto dos pássaros, ver flores raras, de diversas cores, vivenciar o isolamento geográfico e conhecer o modo de vida dos nativos. Todos esses aspectos tornaram-se riquezas no campo do ecoturismo e do turismo comunitário. A unidade tem o ICMBio como seu órgão gestor, e nessa perspectiva, o grande desafio dos moradores e gestores foi tornar as riquezas da RESEX atrativa para a população urbana, sem interferir, de forma negativa na natureza e na dinâmica do lugar (ARAÚJO, 2012).

Desse modo, o turismo foi desenvolvido na RESEX Chico Mendes, através de um produto elaborado pela comunidade chamado "Trilha Chico Mendes", que consiste em uma trilha de até $93 \mathrm{~km}$ de extensão em seu trajeto terrestre, mais um trecho fluvial em embarcações típicas pelo rio Xapuri, com duração de $2 \mathrm{~h} 30 \mathrm{~min}$ à $3 \mathrm{~h}$ de viagem. Esse produto turístico foi reconhecido em 2010 pelo órgão oficial de turismo no Acre, sendo que as atividades desenvolvidas proporcionam a interação dos turistas com a natureza, inserindo também a comunidade local no processo que além de gerar recursos, é capaz de promover o desenvolvimento econômico ambientalmente sustentável através de práticas de ecoturismo que trazem valorização para área (ARAÚJO, 2012).

Portanto, o desenvolvimento do turismo ecoturismo ou o turismo de base comunitária no interior das RESEX é uma oportunidade da própria comunidade local decidir os rumos da atividade turística dentro de seus territórios, bem como é uma forma de reconhecimento e preservação da natureza e da cultura local.

No estado do Pará há também iniciativas para o desenvolvimento do turismo em RESEX, dentre elas destacamos a categoria REM que atualmente encontra-se em expansão na região amazônica. Atualmente, existem no litoral do Pará onze (11) REM, esse número tem crescido nos últimos anos devido o interesse do Governo Federal em criar na Amazônia um modelo de desenvolvimento baseado na sustentabilidade e preservar os ecossistemas da região do Salgado Paraense. 
É importante destacar que, essas áreas possuem potencial turístico, principalmente por possuir paisagens e modo de vida diferenciado. Das unidades presentes no litoral do paraense, destaca-se a REM Mãe Grande de Curuçá, que busca desenvolver no seu interior atividades de turismo sustentável.

A REM Mãe Grande Curuçá está localizada no nordeste paraense, no município de Curuçá e pertence ao Polo Amazônia-Atlântica. Curuçá por sua importância turística possui a diretoria do polo. Desse modo, a REM Mãe Grande Curuçá apresenta um grande potencial turístico, cultural e ambiental que é valorizado, tanto pela população local, como pela Secretaria Municipal de turismo (SEMTUR), que desde 2008 busca desenvolver políticas e ações direcionadas ao turismo no município (FALCÃO, 2013).

Ainda segundo Falcão (2013) atualmente a SEMTUR de Curuçá, desenvolve trabalhos de conscientização com os atores sociais envolvidos na prestação dos serviços turísticos, bem como, busca conscientizar o turista que visita a REM, através da distribuição de materiais sobre a questão ambiental. Segundo o SNUC a visitação pública é permitida no interior da unidade, desde que seja compatível com os interesses locais e de acordo com o Plano de Manejo da área (BRASIL, 2000).

$\mathrm{Na}$ REM há também a atuação de grupos sociais organizados, que desenvolvem oficinas sobre educação ambiental para os moradores e impulsiona o ecoturismo na área. O Instituto Peabiru com o projeto "Casa da Virada", atuou juntamente com a comunidade da REM em projetos de educação ambiental, em que o ecoturismo e o turismo de base comunitária foram as estratégias de inserção socioeconômica, formando grupos de monitores em suas próprias comunidades (FALCÃO, 2013).

Desse modo, Curuçá com o seus atrativos culturais e naturais, tem um grande potencial para desenvolver ecoturismo ou turismo comunitário que pode ser utilizado como importante fator de difusão da educação ambiental, da preservação e da geração de renda. Desse modo, a implementação do turismo de base comunitárias em REM pode promover uma série de benefícios, não só para as comunidades locais, mas também para os visitantes.

\section{Reserva extrativista marinha Mestre Lucindo}

A REM Mestre Lucindo (Figura 1) localizada no município de Marapanim foi criada pelo Decreto S/N 4.340 em 10 de outubro de 2014, com os objetivos de garantir a conservação da biodiversidade dos ecossistemas de Manguezais, restingas, dunas, várzeas, campos alagados, rios, estuários e ilhas e de assegurar o uso sustentável dos recursos naturais pelas populações tradicionais extrativistas que vivem na região (BRASIL, 2014). 


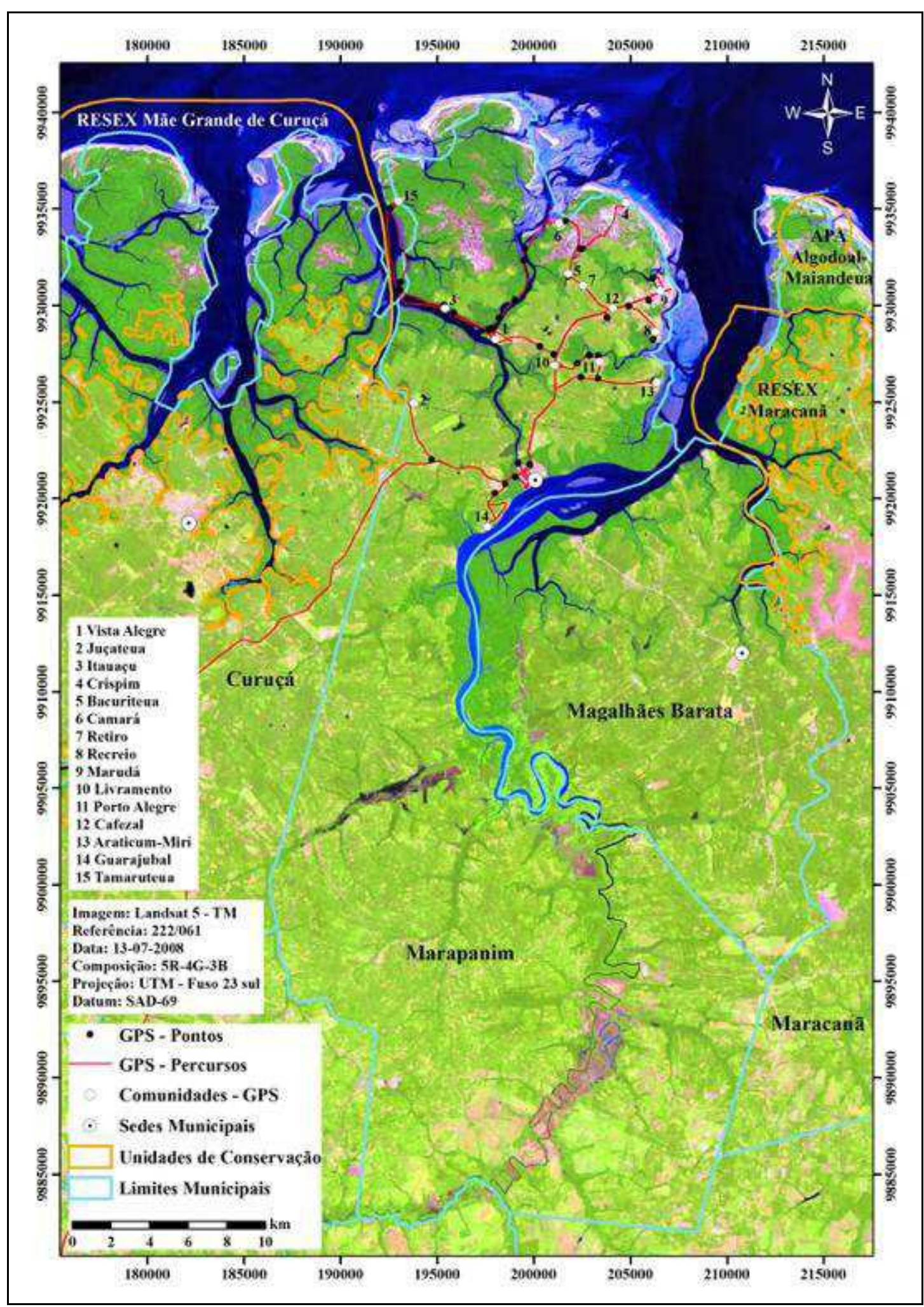

Figura 1: Mapa de limites da REM Mestre Lucindo. Fonte: ICMBio (2014). Figure 1: Map of boundaries of REM Master Lucindo. Source: ICMBio (2014).

Possui uma área de 26.464,88 hectares e destaca-se pela abundância de recursos naturais, associado ao uso tradicional das populações locais. $O$ acesso às comunidades da REM pode ser feito pela estrada asfaltada PA-138, pelas 
estradas vicinais não asfaltadas e pelos rios Cajutuba, Camará e Marapanim (BRASIL, 2014; BRASIL, 2016).

O principal ecossistema da REM é o manguezal, que atualmente encontra-se ameaçado pela excessiva ação antrópica. A exploração do mangue é motivada pela comercialização de caranguejos e pela retirada de madeira nativa, usada para a produção de canoas, currais e lenha. Outro fator preocupante é desmatamento ilegal para a abertura de estradas e o crescimento da ocupação irregular de imóveis e empreendimentos, que são construídos incentivados pelo turismo (BRASIL, 2014).

A REM é de domínio público, sendo que as áreas particulares incluídas em seus limites devem ser desapropriadas de acordo com o que dispõe a lei (BRASIL, 2000). Portanto, moradores de Belém e outros locais que possuem segunda residência, ou trabalham com turismo, precisarão se adequar à nova legislação da área.

A proposta de criação da REM foi uma solicitação encaminhada pelo Centro Comunitário de Marudá, apoiado por instituições do Poder Público Federal e pequenas associações locais, representada por pescadores e coletores da região que vivem essencialmente do extrativismo de recursos pesqueiros (BRASIL, 2014).

Esses atores organizaram-se em um comitê liderado por Luiz Gutemberg que desde 2005 sonhava com a criação da UC no município. Atualmente, ele é o presidente da Associação de Usuários da RESEX Marinha Mestre Lucindo (AUREMLUC), participou ativamente do processo de criação e sempre esteve à frente do movimento na luta pela proteção dos recursos naturais da região (PESQUISA DE CAMPO, 2015).

Durante a pesquisa de campo, em entrevista realizada com seu Luiz Gutemberg, sobre o envolvimento da esfera pública no processo de criação da UC foi esclarecido que:

O que eu tenho para falar é uma coisa difícil de se falar de poder público né. A única esfera que com muita dificuldade pra atender nossa demanda foi o governo Federal através do ICMBio, através do IBAMA, que começou quando era o IBAMA que gerenciava as áreas de RESEX, depois foi instituído o Chico Mendes né? Várias dificuldades atrapalharam a criação da RESEX, o SPU também foi parceiro o SPU foi... Você ver a esfera federal. A SEMMA nunca nos deu atenção do Estado, do município piorou. Os prefeitos que aí passaram nenhum deles acreditaram no processo, a classe empresarial quando a gente conversava só queria saber quando iria chegar os empreendimentos, mas, de ser parceiro pra participar das reuniões, pra vim nunca vieram. (INFORMAÇÃO VERBAL, 2015). 
Percebeu-se o desinteresse do Estado e também do município em relação proposta de criação da UC. Fato evidenciado na entrevista com o senhor Silvio Modesto que respondeu "não houve participação direta e que secretaria de meio ambiente foi em algumas reuniões" (INFORMAÇÃO VERBAL, 2016). Desse modo, nota-se uma falta de articulação e diálogo entre as esferas federal e municipal com a comunidade, e mostra que a secretaria de meio ambiente de Marapanim ainda não compreendeu, de fato, a importância da REM para o município (PESQUISA DE CAMPO, 2016).

No entanto, de acordo com o ICMBio (2014), a solicitação das comunidades para a criação de uma UC em Marapanim ocorreu a partir do incentivo gerado com a chegada dos benefícios à REM Mãe Grande Curuçá. Também, devido a necessidade de reconhecimento dos territórios de pesca que sofrem com constantes invasões de embarcações vindas de outras localidades, necessitando assim, de uma fiscalização mais efetiva na região.

Inicialmente, as reuniões para solicitação de criação da UC ocorreram em 2006. Nessa ocasião, vários abaixo-assinados foram realizados com moradores das comunidades pesqueiras. Mas, a principal reunião que esclareceu sobre o processo de criação da REM, foi realizada apenas no dia 13 de abril de 2013, na Colônia de Pescadores de Marapanim e teve como objetivo mostrar para a comunidade local os benefícios da UC. Nessa ocasião, o representante do ICMBio, Sr. William Fernandes palestrou sobre as RESEX, explicando quais as competências dos principais envolvidos na criação e gestão dessa UC (BRASIL, 2014; PESQUISA DE CAMPO, 2015).

De acordo com o Estudo Socioambiental, realizado pelo ICMBio na região, a criação de uma UC era alvo de disputa de poder entre líderes comunitários e organizações não governamentais locais, sendo que, para a maioria dos moradores, a criação da REM está diretamente relacionada com a chegada de benefícios, tais como casas e fomentos para a pesca, que venham melhorar sua qualidade de vida (BRASIL, 2014). A REM Mestre Lucindo é constituída de 35 comunidades, sendo divididas em oito (8) Polos: Vista Alegre, Camará, Marudá, Araticum-Miri, Guarajubal, Boa esperança e Remanso.

No entanto, não há um documento ou fonte de pesquisa que disponibilize o número total de familias existentes na REM, pois, os dados oferecidos pelo ICMBio, através do Estudo Socioambiental Referente à Proposta de Criação da Resex, mostram apenas 15 comunidades que juntas somam aproximadamente 2.394 famílias. Desse total, 800 famílias estão no distrito de Marudá, que é composto de "vários bairros-comunidades", sendo também, o principal polo turístico da REM. De um modo geral, as comunidades da REM Mestre Lucindo estão formadas ao redor das igrejas e dos portos ou trapiches e praças (BRASIL, 2014; PESQUISA DE CAMPO, 2015).

$\mathrm{Na}$ REM Mestre Lucindo, a principal fonte de renda das famílias vem da pesca artesanal e as espécies de peixes mais importantes no cenário econômico são: a pescada amarela (Cynoscion acoupa), o camurim (Centropomus spp), a dourada (Branchyplatystoma $s p$ ), pescada gó (Macradon ancylodon), a tainha (Mugil sp) e a curvina (Cynoscion microlepidotus) todos comercializados fresco ou salgado. A pesca é uma atividade predominantemente masculina, na qual a 
participação das mulheres se restringe à coleta de sururus, sarnambis e à cata da massa do caranguejo para comercialização, bem como, concertos de redes e malhadeiras, artigos utilizados na pescaria (BRASIL, 2014).

A agricultura está presente nas comunidades de Bacuriteua, Vista Alegre, Livramento, Araticum-Miri e Porto Alegre, onde o principal produto cultivado é a mandioca (Manihot esculenta, Crantz) que complementa a alimentação das famílias. Na REM há coleta de frutos como o bacuri (Platonia insignis), o caju (Anacardium sp) e o muruci (Byrsonima crassifólia), utilizados para a comercialização in natura ou sobre a forma de polpa. O extrativismo vegetal ocorre principalmente em Marudá, Vista Alegre, Crispim e Camará, onde a produção de artesanatos é motivada pela atividade turística na região (BRASIL, 2014; PESQUISA DE CAMPO, 2015).

O abastecimento de água nas comunidades da REM é via sistema comunitário simplificado formado por um conjunto de caixas d'água, que fazem a distribuição para $100 \%$ das residências em todas as comunidades, exceto em Tamaruteua e Itauaçú onde a água é retirada de um poço coletivo. Este serviço é fornecido pela prefeitura de Marapanim (BRASIL, 2014).

Dentre outros aspectos da questão ambiental no município, tem-se a coleta pública do lixo doméstico, que ocorre apenas nas comunidades de Vista Alegre, Marudá e Araticum-Miri, com frequência de duas ou três vezes por semana, sendo que, no próprio no município de Marapanim há locais com grandes quantidades de lixo. Nas outras comunidades na ausência da coleta os moradores queimam o lixo.

A falha na prestação do saneamento básico traz transtornos à população e ao meio ambiente, pois os impactos ambientais afetam também o ecossistema da REM, haja vista que o problema do lixo doméstico é um problema vivenciado nas comunidades de formam o município.

Dentre os principais problemas ambientais da REM, dos 40 entrevistados, $80 \%$ (32) afirmaram o desmatamento do mangue é o principal problema, seguido da falta de caranguejos e outros mariscos, que segundo os usuários a extração excessiva do caranguejo, está levando a sua extinção em algumas comunidades (PESQUISA DE CAMPO, 2015).

Percebeu-se na pesquisa de campo a preocupação com o aumento do desmatamento na região, e também com a falta de recursos necessários a sobrevivência, pois a maioria dos moradores depende exclusivamente da pesca e do extrativismo, porque as roças que existem não produzem alimento suficiente para a sobrevivência de todos na área da REM.

A REM Mestre Lucindo possui a Associação de Usuários da RESEX (AUREMLUC), criada no dia 14 de novembro de 2014, cujo presidente é Luiz Gutemberg de C. Silva. Porém, até o momento a AUREMLUC não possui uma sede para realizar suas atividades e o escritório da associação encontra-se na residência do Gutemberg. As reuniões sobre os assuntos da REM Mestre Lucindo ocorrem principalmente nas comunidades do Livramento, Guarajubal, Araticum-Miri e Camará (PESQUISA DE CAMPO, 2015). 
Dentre as propostas discutidas pela AUREMLUC, está a formação do Conselho Deliberativo e a construção da sede na comunidade do Livramento pela facilidade de acesso e as propostas do Plano de Manejo da unidade. No entanto, o que chama atenção é que, mesmo após um ano e sete meses de sua criação, a REM não tem gestor nomeado pelo ICMBio (PESQUISA DE CAMPO, 2015).

\section{As Comunidades da REM}

Das 35 comunidades pertencentes à REM Mestre Lucindo, foi possível observar as características naturais e sociais de duas comunidades são elas: Vista Alegre e Tamaruteua.

\section{Comunidade de Vista Alegre}

O Distrito de Vista Alegre (ver figura 2) foi fundado no início do século $X X$ por familias oriundas de comunidades vizinhas, que migraram para região em busca de sobrevivência. Localizada a $12 \mathrm{~km}$ de Marapanim na parte noroeste do município, a comunidade foi denominada inicialmente Beira Rio, devido seus moradores construírem suas casas ao longo do rio Cajutuba (FURTADO; HOLANDA, 2005).

Em 1947, o prefeito de Marapanim decidiu mudar o nome da comunidade que passou a se chamar Vista Alegre, devido sua bela paisagem para rio e por ser considerada uma comunidade alegre dentre as comunidades do entorno. Sua expansão ao longo dos anos deu-se em direção à estrada de acesso, onde moradores instalaram-se para praticar a pesca, a agricultura e a criação de gado. Atualmente, Vista Alegre enfrenta o problema da especulação imobiliária motivada pelo turismo de segunda residência (FURTADO; HOLANDA, 2005; PESQUISA DE CAMPO, 2015).

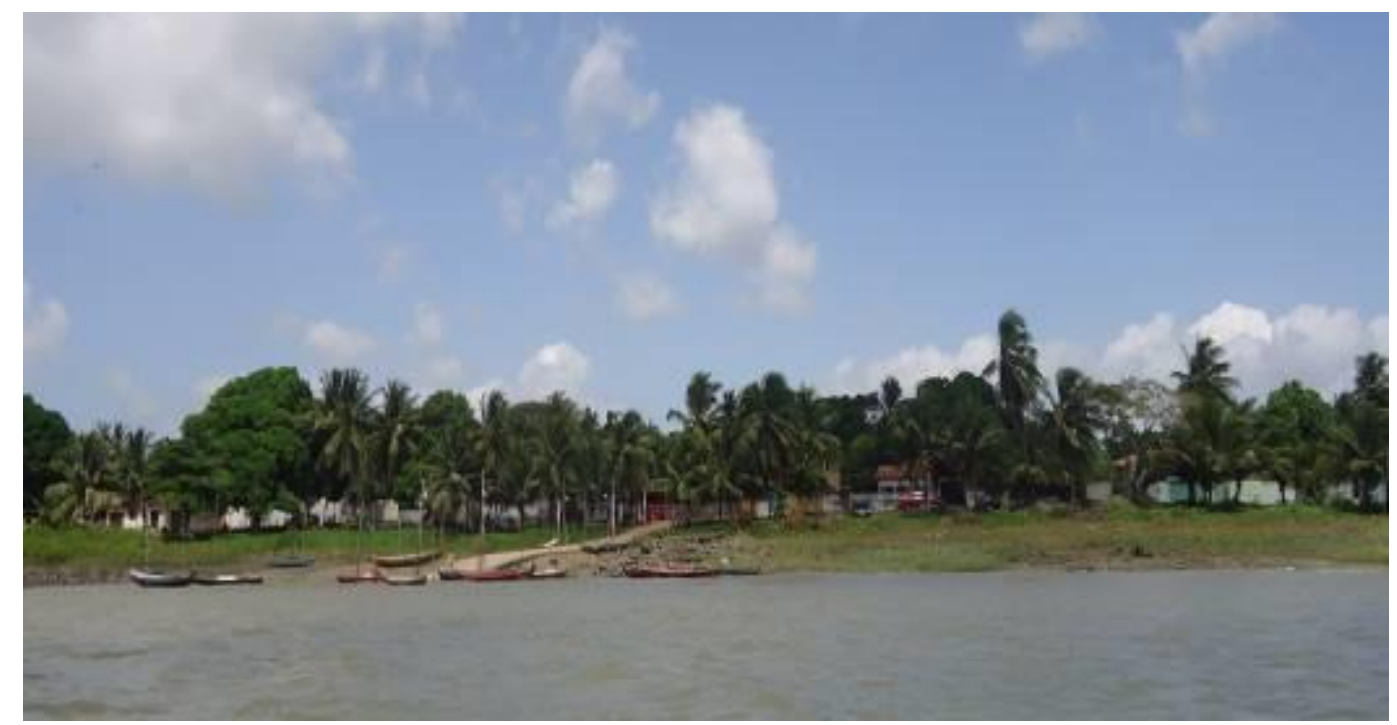

Figura 2: Comunidade Vista Alegre. Fonte: Pesquisa de Campo (2015).

Figure 2: Vista Alegre Community. Source: Field Research (2015). 
Comunidade de Vista Alegre possui aproximadamente 420 familias que vivem principalmente, da pesca e da coleta (crustáceos e mariscos), sendo que alguns moradores praticam, também, a agricultura que é inexpressiva na qual a mandioca é o item mais cultivado (BRASIL, 2014). Em Vista Alegre, além das atividades de uso do ecossistema local existe uma fábrica de gelo que abastece os pescadores do distrito e as comunidades vizinhas, sendo de grande importância, pois ajuda na conservação do pescado tão abundante nesta área (BRASIL, 2014; PESQUISA DE CAMPO, 2015).

O padrão habitacional dos moradores de Vista Alegre em sua maioria é de alvenaria, existindo, também, algumas residências de madeira, sendo que todas as casas possuem energia elétrica. Nos quintais os moradores geralmente mantêm o fogão à lenha. Esse espaço é uma extensão da cozinha onde há, também, pequenos depósitos para guardar o material da pesca (PESQUISA DE CAMPO, 2015).

Em relação à infraestrutura da comunidade, Vista Alegre possui igrejas Católicas e Evangélicas, portos, trapiches e rampas que de acordo com os moradores são, tanto públicos, quanto privados utilizados para desembarque e armazenamento de pescado. Há, também, escolas que oferecem ensino fundamental completo e ensino médio, um posto de saúde e uma delegacia (PESQUISA DE CAMPO, 2015).

Como equipamento de lazer a comunidade possui igarapés e uma praça que representa ponto de encontro dos moradores locais. Sobre o saneamento da comunidade, observou-se que, a mesma possui água potável que chega através do sistema comunitário da prefeitura e de poço artesiano nas residências. O lixo é recolhido duas ou três vezes por semana, no entanto, quando não há a prestação do serviço os moradores queimam ou enterram o lixo no quintal (PESQUISA DE CAMPO, 2015).

Em Vista Alegre as manifestações culturais seguem na sua maioria o calendário de Marapanim, devido à proximidade com a sede do município. Desse modo, há na comunidade, alguns grupos de carimbó, no qual, a presença de jovens é marcante, pois são atraídos pela música, dança e pelos instrumentos (BRASIL, 2014; PESQUISA DE CAMPO, 2015).

\section{Comunidade de Tamaruteua}

A vila de Tamaruteua foi fundada por um grupo de pescadores de Marapanim nas primeiras décadas do século XX que no decorrer de uma expedição encontraram uma praia na ilha de Cajutuba, próximo ao igarapé do Breu. Esta área, desde então passou a ser utilizada para refúgio de pescadores durante os longos períodos de pesca. Desse modo, surgiu a Vila de Tamaruteua que inicialmente localizava-se às margens do Rio Cajutuba. Em 1980, devido a um fenômeno natural a mar avançou sobre a área ocupada e os moradores foram obrigados a sair do local, estabeleceram-se, portanto, em uma área próxima ao igarapé do Breu, que denominaram Nova Tamaruteua (FURTADO; HOLANDA, 2005). 
É considerada a comunidade mais distante da sede municipal, dessa forma o acesso à ilha é somente de barco pelo mar ou pelo rio Cajutuba. Seu ecossistema é composto por igarapés rios, praias e o manguezal que abriga diversas espécies de animais como: caranguejos, turu (Teredo sp), camarões e aves aquáticas (guarás, garças brancas, gaivotas e maçaricos) que fazem seus ninhos neste ambiente. Os rios e igarapés são elementos importantes no cotidiano da comunidade local, além de ser a principal via de acesso à ilha é, também, fonte de subsistência dos habitantes de Tamaruteua que retiram o sustento de suas familias através da pesca e da mariscagem (FURTADO; HOLANDA, 2005).

$\mathrm{Na}$ vila as habitações são de madeira ou alvenaria (ver figura 3), cobertas com telhas de barro ou palha. A cozinha e o sanitário geralmente estão localizados nos quintais, assim como, pequenos depósitos que guardam o material de trabalho, como redes de pesca e utensilios para a mariscagem. Como nas demais comunidades da REM a principal fonte de renda em Tamaruteua é a pesca artesanal que movimenta o comércio na ilha. A vila de pescadores possui, também, a Associação de Pescadores de Tamaruteua (PESQUISA DE CAMPO, 2015).

Os principais problemas enfrentados pelos moradores de Tamaruteua são a falta de água e a falta de energia elétrica. A comunidade não possui água encanada, desse modo, o abastecimento é feito por um poço que não oferece água de qualidade para os moradores. $O$ fornecimento de energia ocorre através de um gerador que é movido a diesel que funciona apenas 5 horas por dia, das 18 às 23 horas. Os moradores fornecem $50 \%$ do valor para a compra do óleo e a prefeitura de Marapanim os outros $50 \%$. Entretanto, moradores relataram que nem sempre a prefeitura dá sua contribuição, restando para a população assumir as despesas, caso contrário a vila fica totalmente sem energia o que representa um grande prejuízo para os pescadores da região (PESQUISA DE CAMPO, 2015).

É importante destacar que em 1999 houve na ilha um projeto da Universidade Federal do Pará (UFPA), realizado pelo Grupo de Estudos e Desenvolvimento de Alternativas Energéticas (GEDAE), intitulado projeto Sistema Hỉbrido Solar-Eólico-Diesel com o objetivo de levar energia à comunidade de Tamaruteua através de fontes alternativas: solar, eólica e diesel (BRASIL, 2014).

Inicialmente, o projeto atendia 47 famílias, mas segundo os moradores não durou muito tempo. Hoje, o projeto encontra-se desativado sendo um motivo de descrença da população local em relação à UFPA. Este episódio foi relatado durante a pesquisa de campo por um dos moradores mais antigos da comunidade, que nasceu na velha Tamaruteua. No entanto, esse distanciamento da comunidade pode ser observado e refletiu no andamento da pesquisa, haja vista que, muitos moradores não quiseram participar ao saber que pertencíamos à instituição (BRASIL, 2014; PESQUISA DE CAMPO, 2015). 


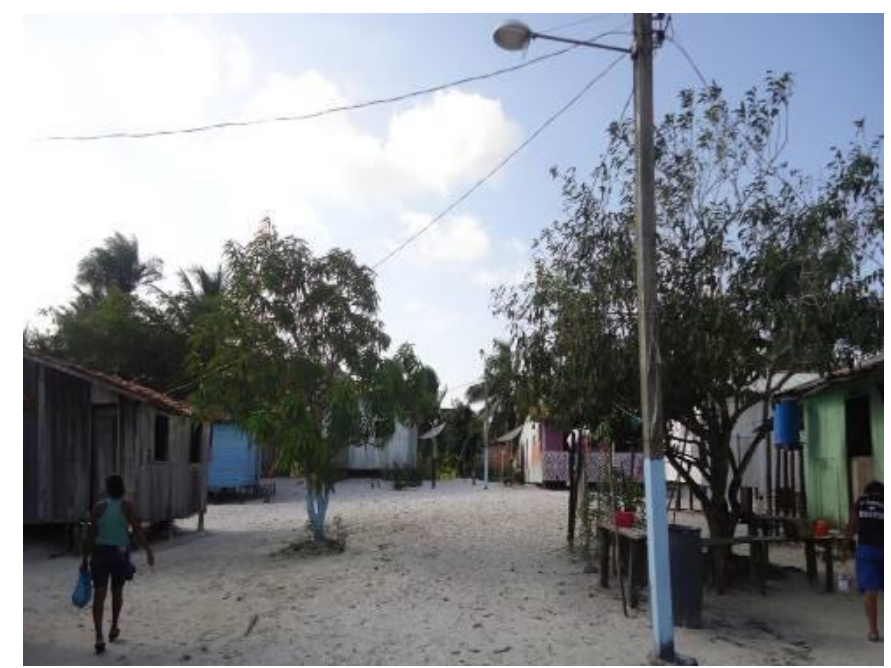

Figura 3: Vista da Vila de Tamaruteua. Fonte: Pesquisa de Campo (2015).

Figure 3: View of the village of Tamaruteua. Source: Field Research (2015).

Sobre a infraestrutura observada na vila de Tamaruteua, há apenas uma escola para crianças até a $4^{\circ}$ série do ensino fundamental, a partir de então, é preciso deslocar-se para Marapanim onde há escolas de ensino fundamental e médio. A comunidade não possui posto de saúde e o serviço é oferecido por agentes comunitários. Quanto aos equipamentos de lazer, há na comunidade um campo de futebol onde moradores se reúnem para jogar e igarapés e praias fazem a diversão de todos na comunidade (PESQUISA DE CAMPO, 2015).

Dentre os principais problemas sociais da comunidade estão o tráfico de drogas e a prostituição, haja vista, a grande mobilidade de pessoas, pois Tamaruteua é ponto de descanso de pescadores e também área de negociação do pescado. Sobre o aspecto religioso, grande parte da população possui como religião o catolicismo, sendo que todo mês de junho ocorre a festividade de São Pedro, padroeiro da comunidade e santo protetor dos pescadores. Há também em Tamaruteua uma igreja evangélica denominada: Igreja de cristo que foi fundada por pastores norte-americanos em 1999 (PESQUISA DE CAMPO, 2015).

\section{Participação e envolvimento da comunidade com a REM}

As informações obtidas durante a pesquisa de campo através de entrevistas, conversas e questionários, permitiu avaliar a percepção das comunidades em relação à criação da REM Mestre Lucindo, bem como a participação social no processo. Foram aplicados em campo 40 (quarenta) questionários estruturados com perguntas abertas e fechadas com os moradores locais das comunidades de Vista Alegre, Tamaruteua, Recreio, Guarajubal, Livramento, Crispim, Marudá, Camará, Santa Maria e a cidade de Marapanim.

Quando questionados sobre a participação no processo de criação da RESEX $60 \%$ (24) dos entrevistados disseram que não conhecem ou não sabem que houve a criação de uma REM no município, e nem tão pouco conseguem explicar, o que significa uma REM. 
Por outro lado, 40\% (16) dos entrevistados afirmaram ter conhecimento sobre a criação de uma REM no município através das reuniões, oficinas e palestras realizadas pelo ICMBio, ou reuniões realizadas pelo senhor Luiz Gutemberg atual presidente da AUREMLUC. No entanto, quando questionados se sabem o que é um Reserva Extrativista, apenas duas pessoas tentaram responder, dizendo que "ajuda a comunidade e o meio ambiente"; "preservação do meio ambiente" (PESQUISA DE CAMPO, 2015).

Percebeu-se no decorrer da pesquisa e na fala dos entrevistados que a maioria deles associa a criação da UC com a chegada de benefícios às comunidades, tendo em vista as mudanças que ocorreram na RESEX Mãe Grande Curuçá, próxima a RESEX Mestre Lucindo. Essa análise, foi feita também, pelo ICMBio durante a pesquisa de campo para elaboração do estudo socioambiental de criação da RESEX, que a chegada de UC ao munícipio iria trazer infraestrutura de moradia, emprego, proteção dos recursos pesqueiros e ordenamento do território de pesca na região (BRASIL, 2014; PESQUISA DE CAMPO, 2015).

Quando questionados sobre os benefícios esperados com a criação da REM, Edmundo Favacho, 60 anos, morador e gestor do comitê da comunidade do Guarajubal respondeu que, "muita coisa pode acontecer e o progresso chegar mais rápido"; Elizane Brito, 28 anos, moradora da comunidade de Vista Alegre respondeu que "conscientização da população com relação ao desmatamento"; Santana da Silva, 52 anos, moradora da comunidade do Livramento espera que "muita coisa melhore e regate pelo menos $50 \%$ do que já foi desperdiçado" (PESQUISA DE CAMPO, 2015).

Desse modo, podemos perceber que, os anseios da população local com a chegada da REM é a mudança de infraestrutura nas suas comunidades, que de certa forma são carentes de serviços de saúde, segurança, saneamento básico, educação entre outras necessidades básicas de sobrevivência. Portanto, é comum que vejam na REM uma oportunidade de mudança, uma melhora na qualidade de vida.

Quanto ao quesito ser a favor ou contra a criação da criação da REM, das 40 pessoas entrevistadas, apenas duas (2) pessoas, disseram ser contra da criação da RESEX, pela falta de informação sobre um processo tão importante da participação popular. As demais embora não entendam perfeitamente o que é a REM manifestaram ser a favor devido as melhorias que podem chegar ao município. Já sete 7 moradores disseram não são nem a favor, nem contra a criação da unidade, por não terem tido conhecimento e nem participado de nenhuma reunião, mostraram-se desinteressados sobre o assunto (PESQUISA DE CAMPO, 2015).

O relatório socioambiental do ICMBio apresenta a realização das palestras realizadas pelo instituto nas comunidades, que esclarecia sobre a proposta de criação da RESEX. Diante disso, é possível dizer que muitos moradores do município de Marapanim tiveram acesso à informação de criação da REM, participando de forma direta ou indireta do processo de criação da UC, através das reuniões e oficinas realizadas pelo ICMBio, nas suas respetivas comunidades. 
No entanto, nas comunidades mais afastadas do centro do município, como Tamaruteua, grande parte dos moradores afirmou não ter conhecimento sobre a criação da REM Mestre Lucindo e nem tão pouco, sobre as mudanças que vão ocorrer na área com a elaboração do plano de manejo. Neste sentido, estudo de Campos (2008, p.5) mostra que:

[...] Há outros problemas relativos as UC, dentre eles, a não implantação dos planos de manejo e o próprio planejamento de criação das UC, no qual as comunidades não são consultadas. Em muitos casos, essas nem sabem o que significa UC mesmo após já ter sido criada, e muito menos que sua residência faz parte de uma UC [...].

Esse modelo de criação reproduz, ainda, fragmentos do passado e a forma como as Áreas Protegidas eram estabelecidas no país. Desse modo, a ausência desses atores no processo de criação reflete a deficiência na divulgação das reuniões, ou mesmo a falta de interesse dos moradores locais em participar de assuntos que na sua percepção não são importantes, por não conhecerem (PESQUISA DE CAMPO, 2015).

Estudo feito por Lobato e Trindade (2014) sobre a REM Tracuateua mostrou que grande parte da polução local não sabia que fazia parte da UC. Embora as diretrizes do SNUC assegurem a participação das populações locais na criação, implementação e gestão das UC. Porém, é possível perceber que a criação REM Mestre Lucindo não está esclarecida para os moradores, bem como, as mudanças que vão ocorrer nas comunidades em relação as questões ambientais que afetam o modo de vida dessas populações (PESQUISA DECAMPO, 2015).

\section{A Atividade Turística na REM}

A REM Mestre Lucindo possui paisagens naturais, praias oceânicas, furos, igarapés e uma extensa área de mangue, que constituem um rico acervo natural da área. De acordo com a estruturação turística, o estado do Pará está dividido em seis polos turísticos, sendo que, Marapanim está localizado no polo Amazônia Atlântica. Este polo abrange 39 municípios e Marapanim encontra-se entre os 23 prioritários (BRASIL, 2014).

A REM Mestre Lucindo possui diversos atrativos turísticos e culturais, que anteriormente já foi apontado no trabalho. Entretanto destacam-se as praias da região e o carimbó que é responsável pelo principal evento cultural do munícipio como o festival do carimbó realizado pela AMATUR. Na pesquisa de campo os moradores de Vista Alegre, Recreio, Marapanim e Tamaruteua foram questionados sobre qual o principal atrativo turístico da RESEX Mestre Lucindo. Dos entrevistados, $67 \%$ dos disseram que as praias e a natureza são o principal atrativo da REM Mestre Lucindo, seguido do carimbó, que $28 \%$ apontaram como sendo o segundo atrativo turístico mais importante da unidade e 5\% apontaram ambas as coisas (PESQUISA DE CAMPO, 2015). 
Assim, pode-se afirmar que a REM Mestre Lucindo possui, além dos manguezais, dunas e lagos, belíssimas praias oceânicas, onde as mais visitadas são: Marudá, Santa Maria, Crispim e Camará. A praia de Marudá é a mais desenvolvida, por possui um maior fluxo de turistas, assim apresenta também melhor infraestrutura em relação às demais localidades. Seu acesso é facilitado pela rodovia PA-138 (BRASIL, 2014; PRESQUISA DE CAMPO, 2015).

Desse modo, nas comunidades de Crispin, Marudá, Vista Alegre, Camará, o turismo já acontece, porém de forma desordenada e sem planejamento adequado. No Crispim o grande atrativo turístico é a própria praia considerada, pelos turistas a praia de mar mais próxima de Belém. A praia do Crispin também oferece fácil acesso e seu período de maior visitação é mês de julho.

Durante a pesquisa de campo foi possível observar alguns problemas ocasionados pela atividade turística, como, por exemplo, a apropriação desordenada do território na comunidade de Vista Alegre, onde é possível perceber a presença de imóveis que não condizem com a realidade do lugar (PESQUISA DE CAMPO, 2015). Nesse aspecto o presidente da AUREMLUC, Luiz Gutemberg, explicou a presença da atividade turística desordenada na REM Mestre Lucindo e relatou os principais problemas da sua comunidade com 0 turismo.

\begin{abstract}
O turismo ele já acontece aqui né, nós temos uma grande riqueza de fauna, flora e a pesca esportiva que já acontece dentro de algumas comunidades, exemplo aqui a vila de Vista Alegre, Tamaruteua e Itauaçu. Muitas pessoas estão migrando pra cá, comprando as casas de nossos pescadores aí na beira do rio Cajutuba, já fazendo uma segunda residência e isso nos preocupa muito... E eles estão fazendo essa atividade sem nenhuma legalidade. Então o turismo de alguma forma já existe aqui, esse turismo que é a pesca esportiva. (INFORMAÇÃO VERBAL, 2015).
\end{abstract}

Assim, o turismo na área está causando impactos ambientais e sociais para essas comunidades, pois é evidentemente que a REM Mestre Lucindo possui um grande potencial para a atividade turística, mas a forma como ela está sendo desenvolvida gera transtornos, tanto para a comunidade local, como para o ecossistema da UC. Desse modo, compreende-se que qualquer planejamento do turismo na REM, requer participação da comunidade em reuniões nos seus respetivos polos, também via Conselho Deliberativo juntamente com o gestor da RESEX. Nesse processo devem-se ser considerados os aspectos culturais e sociais das comunidades, para que o turismo possa ser inserido no contexto das comunidades como fonte alternativa de renda.

Um fator preocupante na área da REM Mestre Lucindo é a devastação da vegetação costeira que está localizada próximo das praias, tornando-se vulnerável à destruição. Pois, a paisagem destes ambientes atrai o turismo sem planejamento e estimula a abertura de estradas que logo, trazem consigo a especulação imobiliária e o turismo desordenado. Esses fatores causados pelo turismo têm interferido de forma negativa no ecossistema que constitui a 
paisagem litorânea da REM, causando a devastação dos manguezais e restingas (BRASIL, 2014; PESQUISA DE CAMPO, 2015).

Existem na REM comunidades como Tamaruteua onde o turismo não foi colocado como elemento importante para os moradores, devidos as diversas dificuldades de acesso e a falta de infraestrutura básica como saneamento e energia elétrica. Essa realidade é diferente de Marudá, onde se concentram as principais ações turísticas do estado e todos os anos possui alta temporada no verão, ocasionado pelo período de férias. Marudá, embora seja reconhecido como um distrito de grande importância para o turismo no munícipio de Marapanim, o mesmo não possui um plano de turismo que envolva a comunidade, e busque desenvolver o turismo base comunitária (PESQUISA DE CAMPO, 2015).

Coriolano (2009) explica que o turismo comunitário é um turismo feito pela comunidade de forma associativa, onde a geração de renda é distribuída de forma igualitária e não concentrada como no grande capital. O turismo comunitário é um modelo que vai de encontro ao turismo conservador, sendo visto, também, como forma de sobrevivência sendo um novo turismo.

Entretanto, o turismo aparece como uma atividade que gera emprego e renda principalmente nas comunidades de Crispin e no distrito de Marudá, pois os moradores locais concentram suas atividades no período do verão, quando aumenta o fluxo turístico nessas localidades. Na Vila Camará a atividade turística foi apontada pela comunidade como de média importância, como oportunidade de desenvolvimento para a localidade, haja vista que, na comunidade o grande atrativo turístico é a praia de Camará e os igarapés frequentados principalmente no mês de julho por veranistas e compradores de pescado (BRASIL, 2014; PESQUISA DE CAMPO, 2015).

$\mathrm{Na}$ comunidade de Araticum-Miri os moradores prestam serviços para turistas no período de veraneio na comunidade e em outras localidades do entorno que oferecem atrações turísticas. No Araticum-Miri a chegada de serviços de distribuição de água e energia, trouxe melhoria da infraestrutura para a população e gerou crescimento da atividade turística na localidade. Nessa comunidade a moradora Lucivalda, 48 anos, disse que para ela "turismo é o deslocamento de pessoas atraídas pela beleza local".

Diante disso, perguntou-se aos moradores de Vista Alegre, Recreio, Tamaruteua e Marapanim sobre caso haja o desenvolvimento do turismo na REM Mestre Lucindo, qual o interesse deles em trabalhar ou desenvolver alguma atividade relacionada com essa atividade. Dentre os entrevistados $87 \%$ relataram ter interesse em trabalhar com atividade relacionada ao turismo. Mas $13 \%$ dos entrevistados disseram não ter vontade de desenvolver nenhuma atividade que seja fora do seu trabalho atual, no qual que a maioria do público entrevistado são pescadores e coletores da região.

Portanto, verifica-se que a REM Mestre Lucindo possui um grande potencial para o desenvolvimento da atividade turística, não só por suas riquezas naturais, mas também, pelo carisma e hospitalidade dos moradores locais da unidade. Porém, durante a pesquisa de campo a comunidade local da REM não demostrou resistências especificamente ao turismo, mas alguns 
moradores da comunidade de Vista Alegre são contra a chegada dos novos atores atraídos pela possibilidade de desenvolvimento do turismo na área.

\section{Considerações Finais}

O presente trabalho buscou analisar a participação e o envolvimento da comunidade local no processo de criação da REM Mestre Lucindo. Desse modo o objetivo geral desse trabalho foi alcançado, pois foi possível verificar, houve participação da comunidade local, mas não de forma totalmente efetiva. No entanto, este cenário já representa uma mudança no modelo de criação de UC no Estado. O estudo mostrou após sua criação, a REM Mestre Lucindo ainda se depara com a falta de interesse de muitos moradores por não compreender o que é uma REM mantem-se distante dos assuntos da mesma. A falta de interesse também se estende ao poder político administrativo do munícipio de Marapanim.

Sobre à presença da atividade turística, pode-se constatar que REM Mestre Lucindo ainda não possui Plano de Manejo principal instrumento de gestão. Assim, o turismo ocorre de forma desordenada anterior à proposta de criação da REM. Portanto, o turismo na REM Mestre Lucindo deve ser planejado com o objetivo de melhorar a qualidade de vida das comunidades e de proteger o patrimônio natural e cultural. Para isso, é fundamental que a população possa participar, também, da tomada de decisões e da elaboração de projetos e roteiros dentro na área da REM, no qual se propõem o turismo de base comunitário como uma alternativa de desenvolvimento local e geração de renda para as comunidades.

Nessa perspectiva, a população local da REM Mestre Lucindo pode trabalhar com atividades de recepção dos turistas, guia local, prestação de serviços nas pousadas e também adaptando suas residências para receber turistas que queiram um convívio mais próximo com a população local. Todavia, essas atividades devem sempre respeitar a dinâmica local e a cultura dos povos extrativistas.

Porém, verifica-se que o turismo na REM Mestre Lucindo tem produzido desigualdades sociais, impactos ambientais e socioculturais, deixando a maioria da população local à margem dos benefícios gerados pela exploração dessa atividade, bem como dos processos de tomada de decisão e planejamento que envolve o ambiente no qual vivem.

Frente a este contexto tem-se um modelo alternativo de desenvolvimento turístico, o Turismo de Base Comunitária, que possui princípios tais como autogestão, associativismo/cooperativismo, valorização da cultura local e, principalmente, no protagonismo das comunidades locais, visando à apropriação por parte destas dos benefícios advindos do desenvolvimento da atividade. Contudo, todas essas atividades só poderão ser planejadas e realizadas após a criação do plano de manejo da REM.

Dessa forma, o turismo na REM Mestre Lucindo quando planejado deve valorizar o conhecimento tradicional das comunidades, incentivando de maneira sustentável as atividades de caça, pesca, coleta de frutos, agricultura de 
subsistência e a produção artesanal com matéria prima regional. Conscientizar a população de que o turismo é apenas uma atividade complementar à renda familiar, incentivando a manutenção do seu modo de vida tradicional.

Valorizar a cultura local, através da conservação de símbolos culturais como o carimbó, patrimônio imaterial das comunidades receptoras, assim como suas paisagens naturais, festas, ritmos, crenças, e modo de vida, através da interação cultural entre turistas e moradores locais, contribuem para a valorização da própria identidade cultural do território da REM e reforça sua atratividade.

\section{Referências}

ALLEGRETTI, M.H. A construção social e políticas ambientais: Chico Mendes e o Movimento dos Seringueiros. Tese (Doutorado em Desenvolvimento Sustentável Gestão e Política Ambiental) - Universidade de Brasília, 2002.

ARAÚJO. A.B. Turismo comunitário na RESEX Chico Mendes. São Paulo, 2012. Disponível em: <http://trilhachicomendes.blogspot.com.br> Acesso em: 22 de maio de 2016.

BRASIL. Atlas de conservação da Natureza Brasileira Unidades Federais. META LIVROS, São Paulo, 2004.

BRASIL. Blog do Planalto Presidência da República. Brasília: 2014. Disponível em: $<$ http://www.blog.planalto.gov.br>. Acesso em: 05 de março de 2016.

BRASIL. Decreto $n^{\circ}$. 4.340, de 10 de outubro de 2014. Cria a Reserva Extrativista Marinha Mestre Lucindo. Diário Oficial da União. Poder Executivo. Brasilia, DF. Disponível em: <www.planalto.gov.br>. Acesso em: 20 de junho de 2015.

BRASIL. Instituto Brasileiro do Meio Ambiente e dos Recursos Naturais Renováveis. Histórico. Brasília: IBAMA, 2015. Disponível em: <http://www.ibama.gov.br>. Acesso em: 12 de setembro. 2015.

BRASIL. Instituto Chico Mendes de Biodiversidade. Estudo Socioambiental Referente à Proposta de Criação da Reserva Extrativista Marinha no Município de Marapanim, Estado do Pará. Brasília: ICMBIO, 2014.

BRASIL. Instituto Chico Mendes de Biodiversidade. Unidades de Conservação na Amazônia. Brasília: ICMBIO, 2015. Disponível em: $<$ http://www.icmbio.gov.br/portal/biodiversidade/unidades-de-conservacao/biomasbrasileiros/amazonia/>. Acesso em: 18 de dezembro. 2015.

BRASIL. RESEX Marinha Mestre Lucindo. Disponível em: $<$ http://www.icmbio.gov.br/portal/unidadesdeconservacao/biomasbrasileiros/amazonia/unidades-de-conservacao-amazonia/resex-marinha-mestrelucindo>. Acesso em: 04 de maio. 2016. Brasília: ICMBIO, 2016.

BRASIL. Lei $n^{\circ}$. 9.985 de 18 de Julho de 2000. Regulamenta o Art. $225 \S 10$, Incisos I, II, III e VI da Constituição Federal, institui o Sistema Nacional de Unidades de Conservação da Natureza. Diário Oficial da República Federativa do Brasil. Poder Executivo, Brasília, DF, 18 de jul. 2000. Disponível em: <www.planalto.gov.br>. Acesso em: 02 de fevereiro de 2016. 
BRASIL. Ministério do Meio Ambiente. Programa Áreas Protegidas da Amazônia. Brasilia: MMA, 2008. Disponível em: <http://www.mma.gov.br/estruturas/sbf arpa2008/>. Acesso em: 28 fev.2016.

CAMPOS, R.I.R. O Martírio Continua? População local e gestão do patrimônio arqueológico nas UC da Serra dos Marítimos/Andorinhas. Anais do Seminário Internacional - Amazônia e fronteiras do conhecimento. Belém: NAEAUUFPA.

CHAMY, P. 2002. Reservas extrativistas marinhas: Um estudo sobre posse tradicional e sustentabilidade. Anais do I Encontro da Associação Nacional de PósGraduação e Pesquisa em Ambiente e sociedade-ANPPAS. Indaiatuba-SP. Disponível em: <http://www.anppas.org.br/gt/encontro anual/paula\%20Chamy.pdf> . Acesso em: 06 de março. 2016.

COLLIER, J. Antropologia visual: a fotografia como método de pesquisa. São Paulo: EPU/USP, 1973. 208 p.

CORIOLANO, L.N.M.T. O turismo comunitário no nordeste brasileiro. In: BARTHOLO, R; SANSOLO, D.G.; BURSZTYN. Turismo de base comunitária: diversidade de olhares e experiências brasileiras. Rio de Janeiro: Letra e Imagem, 2009.

CUNHA, L.H.O. Reservas Extrativistas: uma alternativa de produção e conservação da biodiversidade. Disponível em: <http://www.usp.br/nupaub/resex.pdf>. Acesso em: 05 de dezembro. 2015.

DIEGUES, A.C.S. O Mito moderno da natureza intocada. São Paulo: Hucitec, 1994.

FALCÃO, L.B. Turismo em RESEX: perspectivas de desenvolvimento, participação social e políticas públicas nas RESEX de Soure e de Curuçá no Pará. (Dissertação de mestrado) - Universidade de Brasília, 2013.

FIGUEIREDO, R.A.A. Nas trilhas dos Ecos do Turismo: perspectivas na RESEX Ipaú Anilzilnho, Baião/PA. 2010. 143f. Monografia (Especialização em áreas Protegidas e Unidades de Conservação) - Núcleo de Altos Estudos Amazônicos, Universidade Federal do Pará, Belém, 2010.

FURTADO, L.G; HOLANDA, M.S.M. O Caderno da Pesca: o uso dos ecossistemas em uma comunidade ribeirinha costeira. Belém: Museu Paraense Emílio Goeldi, 2002.

GONÇALVES, C.W.P. Amazônia, Amazônias. 2 ed. São Paulo: Contexto, 2008.

GONÇALVES, E.P. Conversas sobre iniciação à pesquisa científica. Campinas, SP: Alínea, 2007.

GUERRA, A.J.T.; COELHO, M.C.N. Unidades de Conservação: abordagens e características geográficas. Rio de Janeiro: Bertrand Brasil, 2009.

LABURTHE-TOLRA, P.; WARNIER, J.P. Entologia - antropologia. Petrópolis: Vozes, 1997. 469 p.

LIMA, D.M. Ética e Política Ambiental na Amazônia Contemporânea. In: ESTERCI, N; LIMA, D; LENA, P. (Org.). Boletim Rede Amazônia: diversidade sociocultural e políticas ambientais, Belém, v. 1, n.1, p. 37-43, 2002.

LOBATO, F.C.S.; TRINDADE, L.N. Reserva Extrativista (RESEX) Marinha de Tracuateua e a Percepção da Comunidade Local: Gestão participativa e a possibilidade de turismo. (Trabalho de Conclusão de Curso) Universidade Federal do Pará, 2014. 
MATTOS, F. Unidades de Conservação, Turismo e Inclusão Social: o caso da RESEX Marinha do Delta do Parnaíba. Rio de Janeiro, v. 2, n. 2, p. 2-6, 2008.

MEDEIROS, R. A proteção da natureza: das Estratégias Internacionais e Nacionais às demandas Locais. 2003. 391f. Tese (Doutorado em Geografia) - Universidade Federal do Rio de Janeiro, Rio de Janeiro.

MEDEIROS, R. Evolução das tipologias e categorias de áreas protegidas no Brasil. Ambiente \& Sociedade - v. 9, n. 1, p. 41-58, 2006.

MINAYO, M.C.S.; SANCHES, O. Quantitativo-Qualitativo: oposição ou complementariedade? Cad. Saúde Publ., Rio de Janeiro, v.9, n.3., pp.239-262, jul/set, 1993.

OLIVEIRA, V.R. Desmitificando a pesquisa científica. Belém: Edufpa, 2008.

RIBEIRO, B.G. Amazônia Urgente: Cinco Séculos de História e Ecologia. Brasil: Itatiaia, 1992.

ROSA, M.V.F.P.C.; ARNOLDI, M.A.G.C. A entrevista na pesquisa qualitativa: mecanismos para validação de resultados. Belo Horizonte: Autêntica, 2006.

SARGES, M.N. Belém: riquezas produzindo a belle époque: 1870-1912. Belém: Paka-Tatu, 2010.

VALLEJO, L.R. Unidades de Conservação: uma discussão teórica à luz dos conceitos de território e de políticas públicas. Geographia. v.4, n. 8, pp. 57-78, 2002.

VERÍSSIMO, A. Áreas Protegidas na Amazônia Brasileira: avanços e desafios / [organizadores Adalberto Veríssimo... [et al.] ]. Belém: Imazon; São Paulo: Instituto Socioambiental, 2011.

Raul Ivan Raiol de Campos: Universidade Federal do Pará, Belém, PA, Brasil.

E-mail: raulcampos@ufpa.br

Link para o currículo Lattes: http://lattes.cnpq.br/681533068483520

Mara Dayane Silva Nascimento: Universidade Federal do Pará, Belém, PA, Brasil.

E-mail: maraufpa@yahoo.com.br

Symone da Costa Mendonça: Universidade Federal do Pará, Belém, PA, Brasil.

E-mail: symone.turismo@gmail.com

Data de submissão: 29 de agosto de 2016

Data de recebimento de correções: 05 de maio de 2017

Data do aceite: 05 de maio de 2017

Avaliado anonimamente 